Gender in Agriculture 

Agnes R. Quisumbing - Ruth Meinzen-Dick Terri L. Raney - André Croppenstedt Julia A. Behrman - Amber Peterman Editors

\section{Gender in Agriculture}

Closing the Knowledge Gap 


\author{
Editors \\ Agnes R. Quisumbing \\ Poverty, Health, and Nutrition Division \\ International Food Policy Research \\ Institute (IFPRI) \\ Washington, DC, USA \\ Terri L. Raney \\ The State of Food and Agriculture \\ Agricultural Development Economics \\ Division, Economic and Social \\ Development Department \\ Food and Agriculture Organization \\ of the United Nations (FAO) \\ Rome, Italy \\ Julia A. Behrman \\ Department of Sociology \\ New York University, New York \\ NY, USA
}

\author{
Ruth Meinzen-Dick \\ Environment and Production \\ Technology Division \\ International Food Policy Research \\ Institute (IFPRI) \\ Washington, DC, USA \\ André Croppenstedt \\ Agricultural Development Economics \\ Division, Economic and Social \\ Development Department \\ Food and Agriculture Organization \\ of the United Nations (FAO) \\ Rome, Italy
Amber Peterman
Department of Public Policy
University of North Carolina, Chapel Hill
Chapel Hill, NC, USA

\author{
(C) FAO, 2014 \\ Published by \\ The Food and Agriculture Organization of the United Nations \\ and \\ Springer Science + Business Media B.V., \\ Dordrecht 2014
}

FAO Disclaimer:

FAO encourages the use, reproduction and dissemination of material in this information product. Except where otherwise indicated, material may be copied, downloaded and printed for private study, research and teaching purposes, or for use in non-commercial products or services, provided that appropriate acknowledgement of FAO as the source and copyright holder is given and that FAO's endorsement of users' views, products or services is not implied in any way.

All requests for translation and adaptation rights, and for resale and other commercial use rights should be made via www.fao.org/contact-us/licencerequest or addressed to copyright @ fao.org.

FAO information products are available on the FAO website (www.fao.org) and can be purchased through publications-sales@fao.org.

IFPRI Disclaimer:

This book has been peer reviewed, but has not been subject to a formal review via IFPRI's Publications Review Committee. Any opinions expressed are those of the author(s) and do not necessarily reflect the policies or opinions of IFPRI. 
FAO hardback ISBN 978-92-5-107439-8

FAO paperback ISBN 978-92-5-107182-3

Springer hardback ISBN 978-94-017-8615-7

Springer paperback ISBN 978-94-017-8636-2

ISBN 978-94-017-8615-7

DOI 10.1007/978-94-017-8616-4

ISBN 978-94-017-8616-4 (eBook)

Springer Dordrecht Heidelberg New York London

Library of Congress Control Number: 2014936734

(C) Food and Agriculture Organization of the United Nations 2014

This work is subject to copyright. All rights are reserved by FAO and Springer, whether the whole or part of the material is concerned, specifically the rights of translation, reprinting, reuse of illustrations, recitation, broadcasting, reproduction on microfilms or in any other physical way, and transmission or information storage and retrieval, electronic adaptation, computer software, or by similar or dissimilar methodology now known or hereafter developed.

The use of general descriptive names, registered names, trademarks, service marks, etc. in this publication does not imply, even in the absence of a specific statement, that such names are exempt from the relevant protective laws and regulations and therefore free for general use.

The publisher, the authors and the editors are safe to assume that the advice and information in this book are believed to be true and accurate at the date of publication. Neither the publisher nor the authors or the editors give a warranty, express or implied, with respect to the material contained herein or for any errors or omissions that may have been made.

Printed on acid-free paper

Springer is part of Springer Science+Business Media (www.springer.com) 



\section{Foreword}

The publication of The State of Food and Agriculture 2010-11, Women in agriculture: Closing the gender gap for development, called for renewed attention to the importance of the gender gap in agriculture. This issue had not been addressed in The State of Food and Agriculture 2010-11, Women in agriculture: Closing the gender gap for development since the 1983 special section on "Women in Developing Agriculture." In almost three decades there have been vast changes owing to the structural transformation of the global economy and changes in social and political institutions, yet fundamental social, economic, and political gender inequalities have continued to persist. Clearly, a knowledge gap needed to be closed in order to give policymakers, development practitioners, and civil society tools with which to attempt to close the gender gap.

This volume represents the culmination of a fruitful collaboration between the Food and Agriculture Organization of the United Nations (FAO) and the International Food Policy Research Institute (IFPRI). As the premier global policy advisory body on food and agriculture, FAO is well placed to advise governments on the design and implementation of agricultural policies that reflect the latest advances from empirical research. Since the 1980s, IFPRI has undertaken pathbreaking empirical research that challenged the dominant paradigm that men and women within households behave "as one." Its findings that putting more resources into the hands of women has payoffs in terms of agricultural productivity, health, and nutrition have been influential in the design of a new generation of development projects. In the process leading up to The State of Food and Agriculture 2010-11, FAO commissioned many background papers on gender issues in agriculture, and undertook consultations with researchers and policymakers all over the world. The sheer volume of new evidence meant that all this new knowledge could not be presented in The State of Food and Agriculture 2010-11. Because of IFPRI's contributions to research on gender and development policy, FAO commissioned IFPRI to edit a volume comprising the background papers, and to commission additional papers on specific aspects of gender in agriculture. 
The chapters in this book provide evidence to support the main message of The State of Food and Agriculture 2010-11: closing the gender gap in agriculture will generate significant gains for the agricultural sector and for society. Gender equity in access to and control of productive resources - on the farm, in labor markets, and in the nonfarm economy, as well as in the institutions that support agricultural research, development, and extension-is not merely an issue of political correctness, but an essential aspect of development that can benefit women, men, and their families, and society.

Jomo Kwame Sundaram Assistant Director General Economic and Social Development Department Food and Agriculture Organization of the UN Shenggen Fan Director General Director General's Office International Food Policy Research Institute 


\section{List of Editors}

Agnes R. Quisumbing is a Senior Research Fellow, Poverty, Health, and Nutrition Division, International Food Policy Research Institute.

Ruth Meinzen-Dick is a Senior Research Fellow, Environment and Production Technology Division, International Food Policy Research Institute.

Terri L. Raney is a Senior Economist, and Editor of The State of Food and Agriculture, Agricultural Development Economics Division, Economic and Social Development Department, Food and Agriculture Organization of the United Nations.

André Croppenstedt is an Economist, Agricultural Development Economics Division, Economic and Social Development Department, Food and Agriculture Organization of the United Nations.

Julia A. Behrman, formerly a Research Analyst at the International Food Policy Research Institute, is currently a doctoral student at New York University.

Amber Peterman is an Assistant Research Professor of Public Policy at the University of North Carolina at Chapel Hill. 



\section{Contents}

Part I Closing the Knowledge Gap on Gender in Agriculture

1 Closing the Knowledge Gap on Gender in Agriculture.

Agnes R. Quisumbing, Ruth Meinzen-Dick, Terri L. Raney,

André Croppenstedt, Julia A. Behrman, and Amber Peterman

\section{Part II Data and Methods for Gender Analysis in Agriculture}

2 Understanding Gender and Culture in Agriculture:

The Role of Qualitative and Quantitative Approaches

Julia A. Behrman, Ruth Meinzen-Dick, and Agnes R. Quisumbing

3 Data Needs for Gender Analysis in Agriculture Cheryl Doss

4 If Women Hold Up Half the Sky, How Much of the World's Food Do They Produce? Cheryl Doss

Part III Gender, Assets, and Inputs: Issues at the Farm and Household Levels

5 The Gender Asset Gap and Its Implications for Agricultural and Rural Development.

Ruth Meinzen-Dick, Nancy Johnson, Agnes R. Quisumbing, Jemimah Njuki, Julia A. Behrman, Deborah Rubin, Amber Peterman, and Elizabeth Waithanji

6 Gender Equity and Land: Toward Secure and Effective Access for Rural Women

Susana Lastarria-Cornhiel, Julia A. Behrman,

Ruth Meinzen-Dick, and Agnes R. Quisumbing 
7 A Review of Empirical Evidence on Gender Differences in Nonland Agricultural Inputs, Technology, and Services in Developing Countries

Amber Peterman, Julia A. Behrman, and Agnes R. Quisumbing

8 Rural Women's Access to Financial Services:

Credit, Savings, and Insurance

Diana Fletschner and Lisa Kenney

9 Livestock and Women's Livelihoods

Patti Kristjanson, Ann Waters-Bayer, Nancy Johnson,

Annita Tipilda, Jemimah Njuki, Isabelle Baltenweck,

Delia Grace, and Susan MacMillan

10 Gender and Social Capital for Agricultural Development

Ruth Meinzen-Dick, Julia A. Behrman, Lauren Pandolfelli,

Amber Peterman, and Agnes R. Quisumbing

11 Gender Implications of Poor Nutrition and Health in Agricultural Households

Jody Harris

\section{Part IV Gender and Markets: Moving Beyond the Farm}

12 Promoting Gender-Equitable Agricultural Value Chains:

Issues, Opportunities, and Next Steps.

Deborah Rubin and Cristina Manfre

13 Mainstreaming Gender Sensitivity in Cash Crop

Market Supply Chains

Ruth Vargas Hill and Marcella Vigneri

14 Gender Inequalities in Rural Labor Markets

Jennie Dey de Pryck and Paola Termine

Part V Toward a Gender-Sensitive Agricultural Research, Development, and Extension System

15 A System That Delivers: Integrating Gender into Agricultural Research, Development, and Extension

Ruth Meinzen-Dick, Agnes R. Quisumbing, and Julia A. Behrman

16 Enhancing Female Participation in Agricultural Research and Development: Rationale and Evidence Nienke Beintema

17 Improving Gender Responsiveness of Agricultural Extension Catherine Ragasa

Index 


\section{Abbreviations}

$\begin{array}{ll}\text { AIDS } & \text { Acquired Immunodeficiency Syndrome } \\ \text { ASTI } & \text { Agricultural Science and Technology Indicators } \\ \text { ATMA } & \text { Agricultural Technology Management Agency } \\ \text { AWARD } & \text { African Women for Agricultural Research and Development } \\ \text { BRAC } & \text { Bangladesh Rural Advancement Committee } \\ \text { CBAs } & \text { Collective Bargaining Agreements } \\ \text { CBOs } & \text { Community-Based Organizations } \\ \text { CGIAR } & \text { Consultative Group on International Agricultural Research } \\ \text { CSR } & \text { Corporate Social Responsibility } \\ \text { EADD } & \text { East African Dairy Development } \\ \text { FAO } & \text { Food and Agriculture Organization of the United Nations } \\ \text { FFS } & \text { Farmer Field Schools } \\ \text { GAAP } & \text { Gender, Assets, and Agricultural Program } \\ \text { GAD } & \text { Gender and Development } \\ \text { GDP } & \text { Gross Domestic Product } \\ \text { HIV } & \text { Human Immunodeficiency Virus } \\ \text { ICRW } & \text { International Center for Research on Women } \\ \text { ICTs } & \text { Information Communication Technologies } \\ \text { IFAD } & \text { International Fund for Agricultural Development } \\ \text { IFPRI } & \text { International Food Policy Research Institute } \\ \text { ILO } & \text { International Labour Organization } \\ \text { IOM } & \text { International Organization for Migration } \\ \text { MDGs } & \text { Millennium Development Goals } \\ \text { MFI } & \text { Microfinance Institution } \\ \text { NAADS } & \text { National Agricultural Advisory Services (Uganda) } \\ \text { NARS } & \text { National Agricultural Research Systems } \\ \text { NGOs } & \text { Nongovernmental Organizations } \\ \text { NTAE } & \text { Nontraditional Agricultural Export } \\ \text { OECD } & \text { Organisation for Economic Co-operation and Development } \\ \text { PRA } & \text { Participatory Rural Appraisal } \\ & \end{array}$


R\&D Research and Development

RD\&E Research, Development, and Extension

S\&T Science and Technology

SEWA Self-Employed Women's Association

UNDP United Nations Development Programme

UNESCO United Nations Educational, Scientific, and Cultural Organization

UNIFEM United Nations Development Fund for Women

WID Women in Development 


\section{Contributors}

Isabelle Baltenweck International Livestock Research Institute, Nairobi, Kenya

Julia A. Behrman Department of Sociology, New York University, New York, NY, USA

Nienke Beintema Agricultural Science and Technology Indicators (ASTI) Initiative, Environment and Production Technology Division, International Food Policy Research Institute, Washington, DC, USA

André Croppenstedt Agricultural Development Economics Division, Economic and Social Development Department, Food and Agriculture Organization of the United Nations (FAO), Rome, Italy

Jennie Dey de Pryck Global Forum on Agricultural Research (GFAR), Gender in Agriculture Partnership (GAP), Rome, Italy

Cheryl Doss African Studies and Economics, Yale Center for International and Area Studies, Yale University, New Haven, CT, USA

Diana Fletschner Director of Research, Monitoring and Evaluation, Landesa, Seattle, WA, USA

Delia Grace International Livestock Research Institute, Nairobi, Kenya

Jody Harris Poverty, Health, and Nutrition Division, International Food Policy Research Institute, Washington, DC, USA

Ruth Vargas Hill Senior Economist, World Bank, Washington, DC, USA

Nancy Johnson IFPRI, Agriculture for Nutrition and Health (A4NH), Washington, DC, USA

Lisa Kenney PhD Student, Department of Geography, University of Calgary, Calgary, Alberta, Canada 
Patti Kristjanson CGIAR Program on Climate Change, Agriculture and Food Security (CCAFS), World Agroforestry Centre, Nairobi, Kenya

Susana Lastarria-Cornhiel Emeritus, Department of Urban and Regional Planning, Affiliate, Land Tenure Center and The Women's Studies Program, University of Wisconsin-Madison, Madison, WI, USA

Susan MacMillan International Livestock Research Institute, Nairobi, Kenya

Cristina Manfre Cultural Practice, LLC, Bethesda, MD, USA

Ruth Meinzen-Dick Environment and Production Technology Division, International Food Policy Research Institute (IFPRI), Washington, DC, USA

Jemimah Njuki Senior Program Officer, International Development Research Centre, Nairobi, Kenya

Lauren Pandolfelli Statistician, Evidence and Data for Gender Equality (EDGE), United Nations Statistics Division, New York, NY, USA

Stony Brook University, Stony Brook, NY, USA

Amber Peterman Department of Public Policy, University of North Carolina, Chapel Hill, Chapel Hill, NC, USA

Agnes R. Quisumbing Poverty, Health, and Nutrition Division, International Food Policy Research Institute (IFPRI), Washington, DC, USA

Catherine Ragasa Development Strategy and Governance Division, International Food Policy Research Institute, Washington, DC, USA

Terri L. Raney The State of Food and Agriculture, Agricultural Development Economics Division, Economic and Social Development Department, Food and Agriculture Organization of the United Nations (FAO), Rome, Italy

Deborah Rubin Cultural Practice, LLC, Bethesda, MD, USA

Paola Termine Child Labour in Agriculture, Fundamental Principles and Rights at Work (FPRW), International Labour Organization, Genève 22, Switzerland

Annita Tipilda Global Forests and Climate Change Programme, Nature Based Solutions Group, International Union for Conservation of Nature (IUCN), Gland, Switzerland

Marcella Vigneri Independent Development Economist (Specializing in Agricultural Development and research collaborator for IFPRI 's Ghana Strategy Support Programme [GSSP]), Oxford, UK

Elizabeth Waithanji International Livestock Research Institute, Nairobi, Kenya Ann Waters-Bayer ETC Foundation, Leusden, Netherlands 